See Article page e215.

\section{Commentary: Fluoroquinolone guilt: The evidence mounts}

\author{
John A. Elefteriades, MD, PhD (hon), and \\ Bulat A. Ziganshin, MD, PhD
}

The article "Ciprofloxacin Accelerates Aortic Enlargement and Promotes Dissection and Rupture in Marfan Mice" by LeMaire and colleagues ${ }^{1}$ represents another important plank in the growing platform implicating fluoroquinolones in inducing aortic dissection. As we have come to expect from LeMaire and colleagues' work, the investigation is clinically and academically important, razor-sharply conceived, well executed, and clearly presented.

In a mouse model of Marfan's disease, LeMaire and colleagues ${ }^{1}$ showed that ciprofloxacin treated mice, compared with controls, showed more rapid aortic growth and higher incidence of aortic dissection and aortic rupture. These clinical findings were accompanied by increased elastic fiber fragmentation and smooth muscle cell apoptosis, as well as increased matrix metalloproteinase 2 and 9 expression in the aortic wall. The authors conclude that their data "substantiate that ciprofloxacin should be avoided in patients with Marfan syndrome."

The evidence of the dangerous impact of fluoroquinolones in inducing aortic dissection is growing rapidly, an outshoot from the initial recognition by orhopedists that these drugs produced Achilles tendon ruptures in young athletes. This literature has been reviewed. ${ }^{2}$ Abundant data establish fluoroquinolones as a "smoking gun," although population studies, while highly suggestive of culpability, fall just short of evidence strong enough for absolute conviction.

\footnotetext{
From the Aortic Institute at Yale-New Haven Hospital, Yale University School of Medicine, New Haven, Conn.

Disclosures: J.A.E.: Principal, CoolSpine; Consultant for CryoLife; Data/Safety Monitoring Board for Terumo. B.A.Z. reported no conflicts of interest.

The Journal policy requires editors and reviewers to disclose conflicts of interest and to decline handling or reviewing manuscripts for which they may have a conflict of interest. The editors and reviewers of this article have no conflicts of interest.

Received for publication Oct 20, 2020; revisions received Oct 20, 2020; accepted for publication Oct 21, 2020; available ahead of print Oct 29, 2020.

Address for reprints: John A. Elefteriades, MD, PhD (hon), Aortic Institute at Yale New Haven, 789 Howard Ave, Clinic Building CB317, New Haven, CT 06510 (E-mail: john.elefteriades@yale.edu).

J Thorac Cardiovasc Surg 2022;163:e235-6

$0022-5223 / \$ 36.00$

Copyright (c) 2020 by The American Association for Thoracic Surgery

https://doi.org/10.1016/j.jtcvs.2020.10.090
}

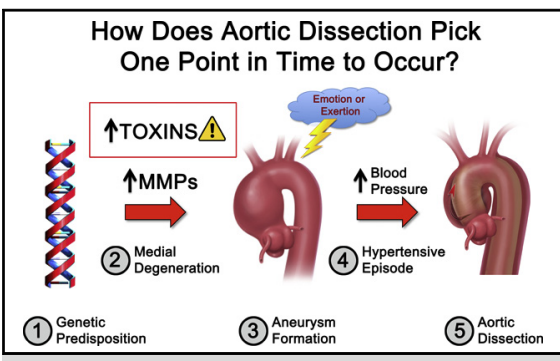

Mechanism of aortic dissection development and potential role of toxins.

\section{CENTRAL MESSAGE \\ The evidence of the dangerous impact of fluoroquinolones in inducing aortic dissection is growing. LeMaire and colleagues caution against the use of fluo- roquinolones in patients with Marfan syndrome.}

We have the following points to make:

1. Mice are not humans. Although the authors' suggestion regarding avoiding fluoroquinolones in humans with Marfan disease seems reasonable, especially when viewed in the context of other accumulating scientific and clinical evidence, ${ }^{3-6}$ one must be wary of one phenomenon: Mice are not humans. Medical science has seen this principle demonstrated time and time again, most recently in the failure of angiotensin receptor blockers to realize in humans the dramatic protective effects against aneurysm disease they had demonstrated in mice. ${ }^{7,8}$ Also, we must remember that although one single, specific mutated allele produces the Marfan mice, the human disease is much more nuanced, with more than 1000 variants currently known to cause the Marfan phenotype.

2. Are patients without inherited aortic disease ("normals") susceptible to fluoroquinolone-induced aortic dissection? It may be difficult to answer the question of whether the fluoroquinolone-conferred susceptibility is so powerful as to be able to induce aortic dissection in a previously normal aorta. In the study by LeMaire and colleagues, ${ }^{1}$ wild-type (ie, non-Marfan mice) given ciprofloxacin did not enlarge their aortas or develop aortic dissection. We have seen that more of our patients with ascending aortic aneurysm or dissection have inherited aortic disease. ${ }^{9-11}$ At the present time, we 


\section{How Does Aortic Dissection Pick One Point in Time to Occur?}

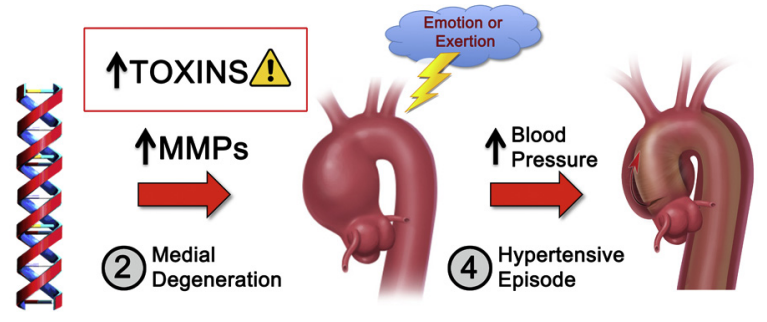

(1) Genetic

(3) Aneurysm

(5) Aortic

FIGURE 1. Susceptibility to aortic aneurysm and dissection is set from birth by genetics. The aortic wall is damaged over time, at least in part because of excess proteolysis by the matrix metalloproteinases. The aorta enlarges as its wall is damaged, resulting in deterioration of its mechanical properties, loss of distensibility, and imposition of excess wall tension. An acute hypertensive event supervenes-usually emotional or exertionaland exceeds the tensile limit of the aortic wall, producing an acute aortic dissection. To this traditional description, we have added the potential role of toxins in damaging the aortic wall. $M M P$, Matrix metalloproteinase. Modified, with permission, from Hatzaras IS, Bible JE, Koullias GJ, Tranquilli M, Singh M, Elefteriades JA. Role of exertion or emotion as inciting events for acute aortic dissection. Am J Cardiol. 2007;100:1470-2.

can identify at least a suspicious genetic "variant of uncertain significance" in one-third of all our patients. The list of offending genes (genetic "dictionary") grows every year, requiring publication on a yearly basis for currency to be maintained. ${ }^{12}$ Our team believes that eventually the majority of patients with ascending aneurysm/dissection will be found to harbor a specific "causative" genetic abnormality, perhaps even nearly all. But do we need to worry only about patients with aneurysm? Can fluoroquinolones induce aortic enlargement and dissection in an anatomically and histologically normal aorta? That remains to be seen.

3. Broader concept of "aortic toxins." In the aortic community, our focus has been on enlarged aortas and the impact of family history and genetic diseases. It seems we may need to think more broadly, specifically to make ourselves aware of a whole group of substances that can fairly be considered "toxic" specifically to the aorta. These include a variety of medications (glucocorticoids, phosphodiesterase-5 inhibitors [sildenafil], vascular endothelial growth factor inhibitors, anticoagulants, fibrinolytics, cocaine, amphetamine, and methamphetamine [3,4-methylenedioxymethamphetamine, ecstasy], cocaine). ${ }^{13}$ Implicated nonmedicinal toxins include tobacco, ${ }^{14}$ cadmium, ${ }^{15}$ and $\mathrm{N}$-(2-aminoethyl) ethanolamine (used in fabric softeners, cleaners, coatings, fuels, and lubricants). ${ }^{16}$ Accordingly, we have added toxins to our schematic diagram (J.A.E.) used to illustrate the general pathophysiology leading to aortic dissection (Figure 1).
4. Contrary opinions. It is important to keep in mind that population-wide studies of relationships like that of fluoroquinolone use and aortic dissection are fraught with difficulties. Definition of aneurysm or dissection may be imprecise in large administrative databases. Fluoroquinolone dosage and duration of administration are difficult to assess. Confounding variables abound. This is apparent in 2 recent large-scale studies that have questioned the causative relationship between fluoroquinolones and aortic dissection. ${ }^{17,18}$ We are believers in this relationship, but we agree that further investigation is needed.

We thank our colleagues from Baylor for yet another important contribution to the understanding of the causes and treatment of aortic disease.

\section{References}

1. LeMaire SA, Zhang L, Zhang NS, Luo W, Barrish JP, Zhang Q, et al Ciprofloxacin accelerates aortic enlargement and promotes dissection and rupture in Marfan mice. J Thorac Cardiovasc Surg. 2022;163:e215-26.

2. Carino D, Zafar MA, Singh M, Ziganshin BA, Elefteriades JA. Fluoroquinolones and aortic diseases: is there a connection? Aorta (Stamford). 2019;7:35-41.

3. Daneman N, Lu H, Redelmeier DA. Fluoroquinolones and collagen associated severe adverse events: a longitudinal cohort study. BMJ Open. 2015;5:e010077.

4. Lee CC, Lee MT, Chen YS, Lee SH, Chen YS, Chen SC, et al. Risk of aortic dissection and aortic aneurysm in patients taking oral fluoroquinolone. JAMA Intern Med. 2015;175:1839-47.

5. Pasternak B, Inghammar M, Svanstrom H. Fluoroquinolone use and risk of aortic aneurysm and dissection: nationwide cohort study. BMJ. 2018;360:k678.

6. Lee CC, Lee MG, Hsieh R, Porta L, Lee WC, Lee SH, et al. Oral fluoroquinolone and the risk of aortic dissection. J Am Coll Cardiol. 2018;72:1369-78.

7. Habashi JP, Judge DP, Holm TM, Cohn RD, Loeys BL, Cooper TK, et al. Losartan, an AT1 antagonist, prevents aortic aneurysm in a mouse model of Marfan syndrome. Science. 2006;312:117-21.

8. Lacro RV, Dietz HC, Sleeper LA, Yetman AT, Bradley TJ, Colan SD, et al. Atenolol versus losartan in children and young adults with Marfan's syndrome. N Engl J Med. 2014;371:2061-71.

9. Albornoz G, Coady MA, Roberts M, Davies RR, Tranquilli M, Rizzo JA, et al. Familial thoracic aortic aneurysms and dissections-incidence, modes of inheritance, and phenotypic patterns. Ann Thorac Surg. 2006;82:1400-5.

10. Elefteriades JA. Thoracic aortic aneurysm: reading the enemy's playbook. Curr Probl Cardiol. 2008;33:203-77.

11. Ziganshin BA, Bailey AE, Coons C, Dykas D, Charilaou P, Tanriverdi LH, et al. Routine genetic testing for thoracic aortic aneurysm and dissection in a clinical setting. Ann Thorac Surg. 2015;100:1604-11.

12. Faggion Vinholo T, Brownstein AJ, Ziganshin BA, Zafar MA, Kuivaniemi H, Body SC, et al. Genes associated with thoracic aortic aneurysm and dissection: 2019 update and clinical implications. Aorta (Stamford). 2019;7:99-107.

13. Spigset O. Drug-induced aortic aneurysms, ruptures and dissections. In: Grundmann R, ed. Etiology, Pathogenesis and Pathophysiology of Aortic Aneurysms and Aneurysm Rupture. London: IntechOpen; 2011.

14. Folkesson M, Sadowska N, Vikingsson S, Karlsson M, Carlhäll CJ, Länne T, et al. Differences in cardiovascular toxicities associated with cigarette smoking and snuff use revealed using novel zebrafish models. Biol Open. 2016;5:970-8.

15. Fagerberg B, Borne Y, Sallsten G, Smith G, Acosta S, Persson M, et al. Circulating cadmium concentration and risk of aortic aneurysms: a nested case-control study within the Malmo Diet and Cancer cohort. Atherosclerosis. 2017;261:37-43.

16. Chen Z, Xu Y, Bujalowski P, Oberhauser AF, Boor PJ. N-(20Aminoethyl) ethanolamine-induced morphological, biochemical, and biophysical alterations in vascular matrix associated with dissecting aortic aneurysm. Toxicol Sci. 2015;148:421-32.

17. Dong YH, Chang CH, Wang JL, Wu LC, Lin JW, Toh S. Association of infections and use of fluoroquinolones with the risk of aortic aneurysm or aortic dissection. JAMA Intern Med. 2020:e204192.

18. Gopalakrishnan C, Bykov K, Fischer MA, Connolly JG, Gagne JJ, Fralick M. Association of fluoroquinolones with the risk of aortic aneurysm or aortic dissection. JAMA Intern Med. 2020:e204199. 